\title{
A river journey through Gunung Leuser National Park, Sumatra
}

\author{
Michael P. Ghiglieri
}

The Gunung Leuser National Park, established by the Indonesian Government in 1980, covers more than $7900 \mathrm{sq} \mathbf{~ k m}$ of forests, ranging from tropical lowland to subalpine. It protects many endangered and threatened species. In October 1984 the author, acting as a biologist and guide on an exploratory rafting expedition, floated along the Alas River, which runs through the Park. He describes his journey and the primates he recorded along the way.

The Gunung Leuser National Park, an amalgamation of seven reserves in northern Sumatra, was legally established on 6 March 1980. This conservation triumph followed a decade of effort by the Nature Conservation and Wildlife Management Service (PPA, now PHPA) of Indonesia and the World Wildlife Fund. The Park's approximately $7900 \mathrm{sq} \mathrm{km}$ is divided into four altitudinal zones: tropical lowland (below $600 \mathrm{~m}, 12$ per cent), upland (600-1500 m, 48 per cent), mountainous ( $1500-2500 \mathrm{~m}, 35$ per cent), and subalpine (above $2500 \mathrm{~m}, 5$ per cent) (Van Strien, 1978). More than half the species of mammals found in Sumatra occur there, including populations of endangered and threatened large mammals now extinct over most of their former ranges in the Malay Archipelago and the rest of South East Asia. For example, Gunung Leuser still contains viable populations of Sumatran rhinoceros, ${ }^{*}$ elephant, tiger, clouded leopard, wild dog, Malayan sun bear, orang-utan, siamang, serow and other species (see also Martin, 1983; Blouch, 1984).

Indonesia contains one-tenth of the world's

*Scientific names of animals are given in Table 1.

104 tropical forest (Caufield, 1984), but deforestation is rapidly accelerating (Frey, 1978; Myers, 1984) and patchy remnants of primary forest are increasingly more common than large biocks. In view of this, Gunung Leuser is probably the most important conservation area in South East Asia.

In October 1984, I was a biologist and guide on an exploratory whitewater expedition organized by SOBEK Expeditions Inc. (Angels Camp, California) down the Alas River, which bisects Gunung Leuser National Park. We travelled by inflatable river boat from Agusan, the uppermost point on the Alas accessible within a half-hour's walk from the road (and with adequate flow for a boat), to the southernmost boundaries of the Park, then beyond to the Indian Ocean. During river travel, I recorded all my sightings of large mammals and orang-utan nests within the riparian corridor. In addition, by means of a lowaltitude reconnaissance provided by a Mobil Oil helicopter, we flew from the Ketambe Research Station founded by Herman Rijksen (1978) in 1971 , upstream along the Alas to its source on (Mount) Gunung Leuser, and to the summit. This allowed a quick evaluation of the physical condition of the north-west corner of the Park. The entire $322-\mathrm{km}$ river journey combined with approximately $100 \mathrm{~km}$ (each direction) by air, with $51 \mathrm{~km}$ of air and river travel overlapping, provided a unique opportunity to examine the Park between its most distant boundaries.

The Alas River and its riverine habitats are divided into contrasting sections, both naturally by geographic features and artificially by roads (Figure 1 , Table 2). Section 1, its headwaters on Gunung 


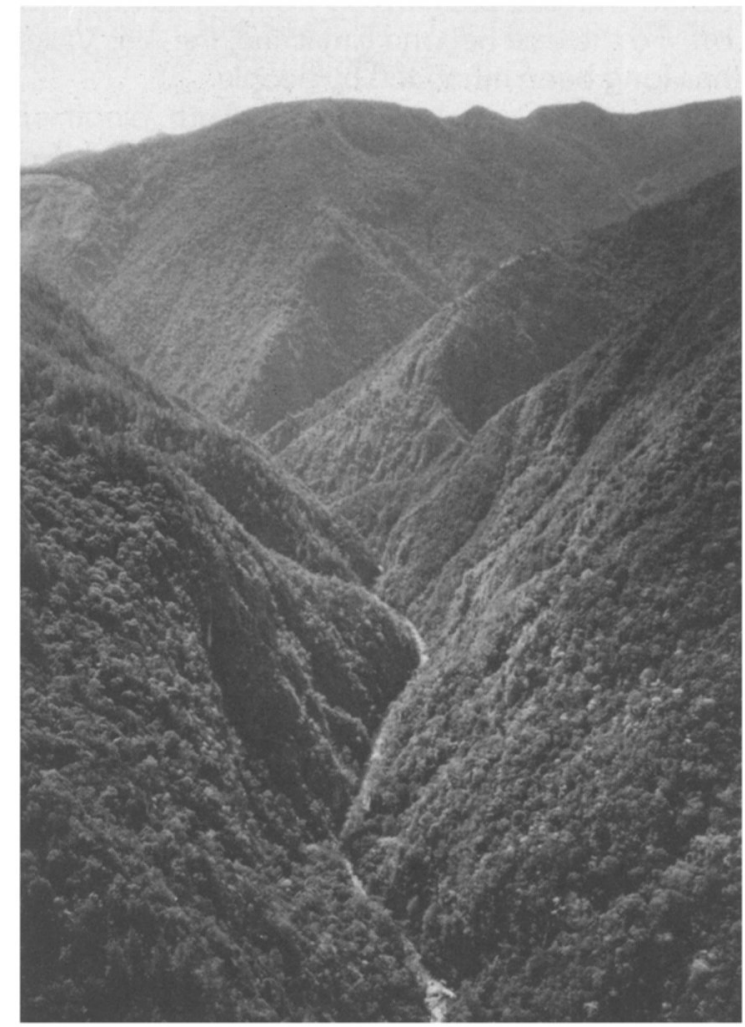

Pristine. primary tropical forest cloaking the steep slopes of Alas River canyon in Section 1. upstream from and isolated from Agusan (M.P. Ghiglieri).

Leuser, extends approximately $50 \mathrm{~km}$ to the village of Agusan (elevation $950 \mathrm{~m}$ ) and is accessible only by foot (or helicopter . . .) along very steep terrain. The rain forest is subalpine and mountainous, with a discontinuous upper canopy studded with emergents at lower elevations, and

Table 1. Scientific names of animals mentioned in the text

\begin{tabular}{ll}
\hline Clouded leopard & Neofelis nebulosa \\
Crab-eating macaque & Macaca fascicularis \\
Elephant & Elephas maximus \\
Gibbon & Hylobates lar \\
Leaf monkey & Presbytis thomasi \\
Malayan sun bear & Helarctos malayanus \\
Orang-utan & Pongo pygmaeus \\
Pig-tailed macaque & Macaca nemestrina \\
Serow & Capricornis sumatrensis \\
Siamang & Hylobates syndactylus \\
Sumatran rhinoceros & Dicerorhinus sumatrensis \\
Tiger & Panthera tignis \\
Wild dog & Cuon alpinus \\
\hline
\end{tabular}

River joumey through Gunung Leuser NP shows no sign of unnatural disturbance. Hunting may occur, but we saw no evidence of it.

Section 2, extending $51 \mathrm{~km}$ from Agusan to the Ketambe Research Station, is mostly steep gorge, but contains $6-10 \mathrm{~km}$ of relatively level riverside land, where there are official non-Park enclaves of human settlement. Within the last five years, the narrow track that runs roughly parallel with the Alas, connecting Kutacane with Agusan, has been paved with tarmac. This has made communication and the marketing of local agricultural produce and natural products of the region much easier, which in turn makes settlement along the road more attractive. There are several villages along the road, and in many places, where the topography permits, the Gayo people have cut small swidden fields of $1-10$ ha along the river.

Despite this, the riverine rain forest upstream of Ketambe is still pristine, with limited evidence of vegetative disturbance. Even after $10 \mathrm{~cm}$ of rain in October, the Alas here ran clear. Primates,

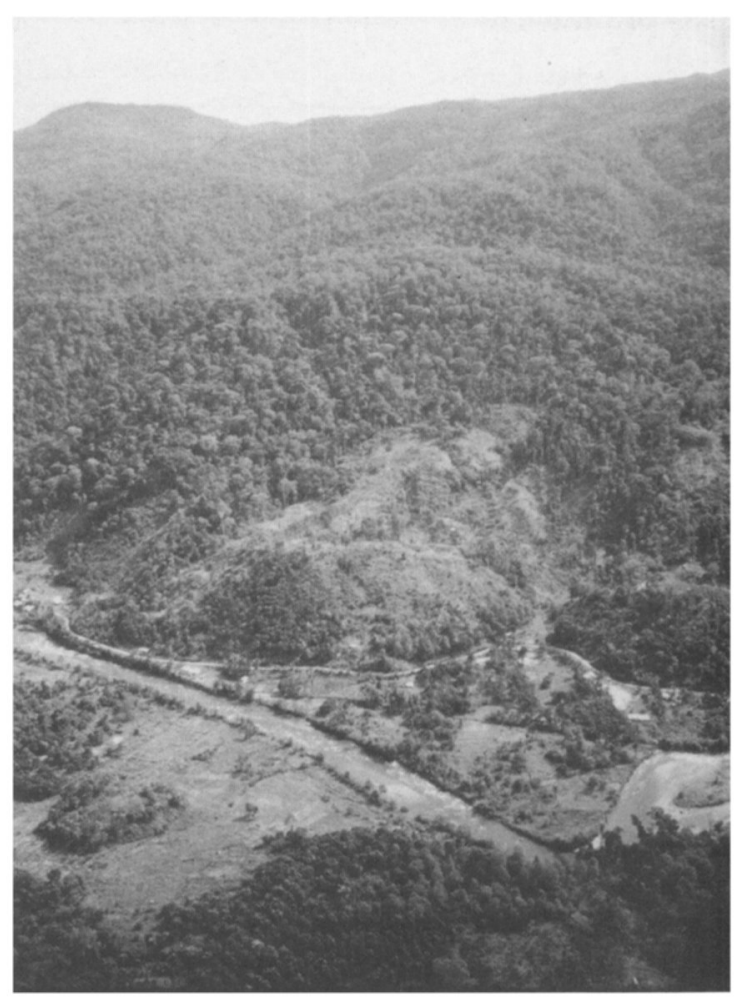

Aerial view of non-park enclave near tarmac road in Section 2 (M.P. Ghiglieri). 
especially crab-eating macaques, leaf monkeys, gibbons and siamang seemed common relative to habitats outside the Park. I saw no orang-utans, but their nests were common locally.

Section 3, extending $60 \mathrm{~km}$ from Ketambe to Muara Setulen, is another elongated enclave on non-Park land (the initial $8 \mathrm{~km}$ or so of this stretch is within the Park). This region is known as the Alas Valley and is populated by thousands of Aceh Alas people, primarily Muslim, plus more recent immigrants of Christian Karo Batak. As one travels downstream from Ketambe, the valley widens and flattens and there is more and more agricultural land. From Kutacane to Muara Setulan, the valley is virtually one patchwork farm dotted with semi-natural plots. Near the river here I saw no non-human primates.

The hills $1-2 \mathrm{~km}$ west of the Alas have been either clear cut, partially felled, or otherwise disturbed. Here, near the confluence with the Mamas River, the Alas became increasingly turbid with silt, presumably from agricultural runoff. To the east beyond Kutacane, the Alas Valley has long been inhabited by people.

Section 4, the Lower Gorge, begins about 2-3 $\mathrm{km}$ downstream of Muara Setulen and extends $32.5 \mathrm{~km}$ to the confluence with the Renun River. The west side of the Alas is in Gunung Leuser. Here the river has carved a course between two mountain ranges (approximately 2000-2500 m elevation). Upstream of the Renun the habitat of the Lower Gorge is pristine rain forest. In order of numbers of sightings, long-tailed macaques, langurs, siamang, lar gibbon and orang-utans and their nests again appeared common.

The river is regularly fished using gill nets. In the forest I found a series of brush fences punctuated with eight polypropylene snares set apparently for argus pheasant. The lower $100-400 \mathrm{~m}$ of the canyon is extremely steep and offers only small fishing camps under rock overhangs. Perhaps

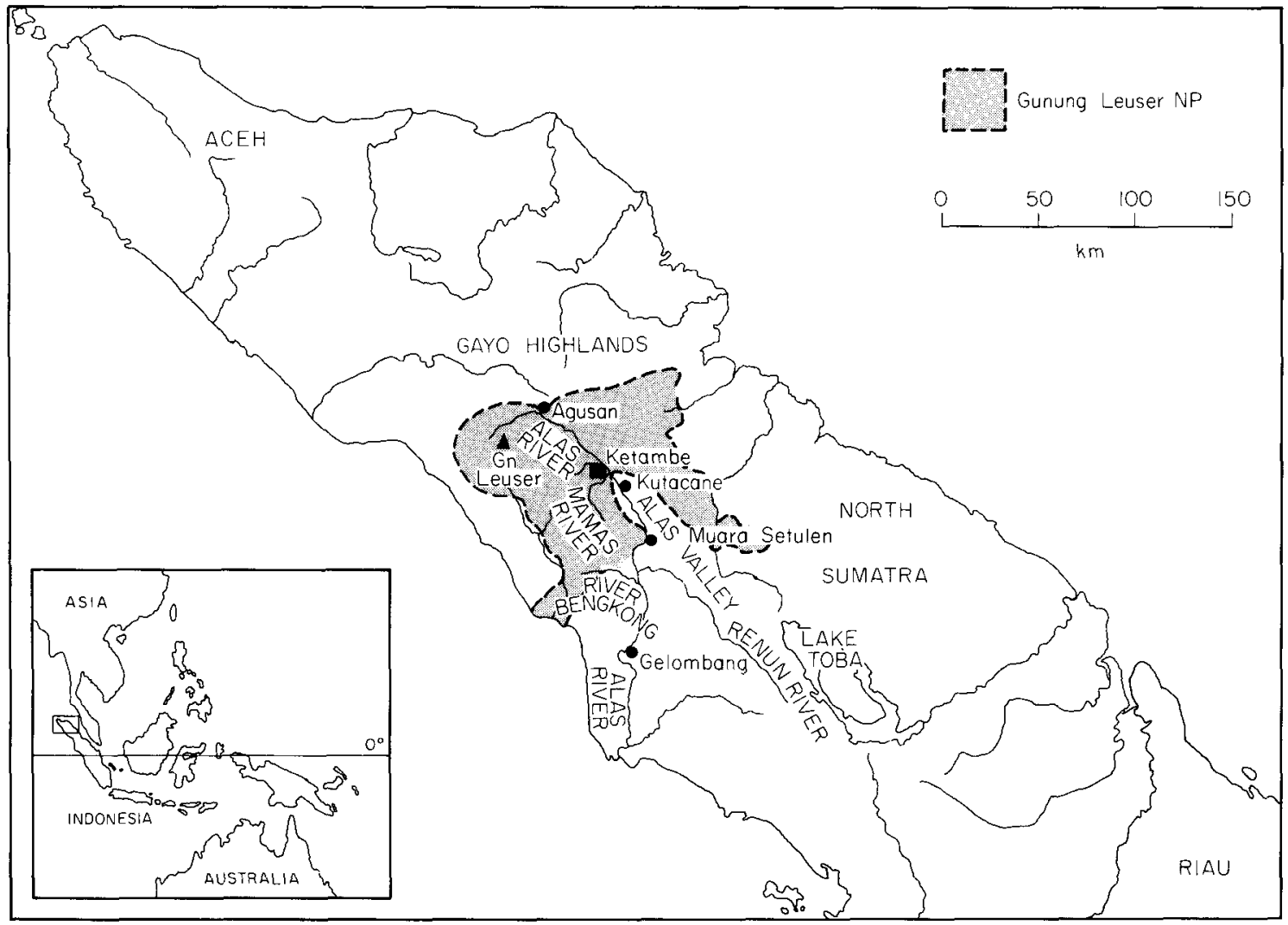

Figure 1. The Gunung Leuser NP, North Sumatra. This map is taken from Rijksen (1978). 
because of the steepness, the forest is virtually undisturbed and magnificent.

Section 5, the final $11 \mathrm{~km}$ of the Lower Gorge, lies between the confluences of the Alas with the Renun [here only a few kilometres west of John MacKinnon's (1974) study site for orang-utan] and with the Bengkong downstream. The Bengkong forms the south-west boundary of Gunung Leuser; the Renun side is unlogged timber concession. Here again, only the west side of the Alas is in the Park. Towards the end of the Lower Gorge, the east side showed increasing signs of exploitation and slash-and-burn agriculture. Poaching of individual trees on both sides became more pronounced. Approximately $5 \mathrm{~km}$ downstream of the Renun confluence a bulldozer was grading a timber extraction road from the east. The operator told me it had taken him 8 months to build the $30 \mathrm{~km}$ of road, then nearly ready for use. In this riparian corridor my sightings

Right: Recently cleared riparian forest adjacent to Alas River in Section 2 in preparation for swidden farming (M.P. Ghiglieri).

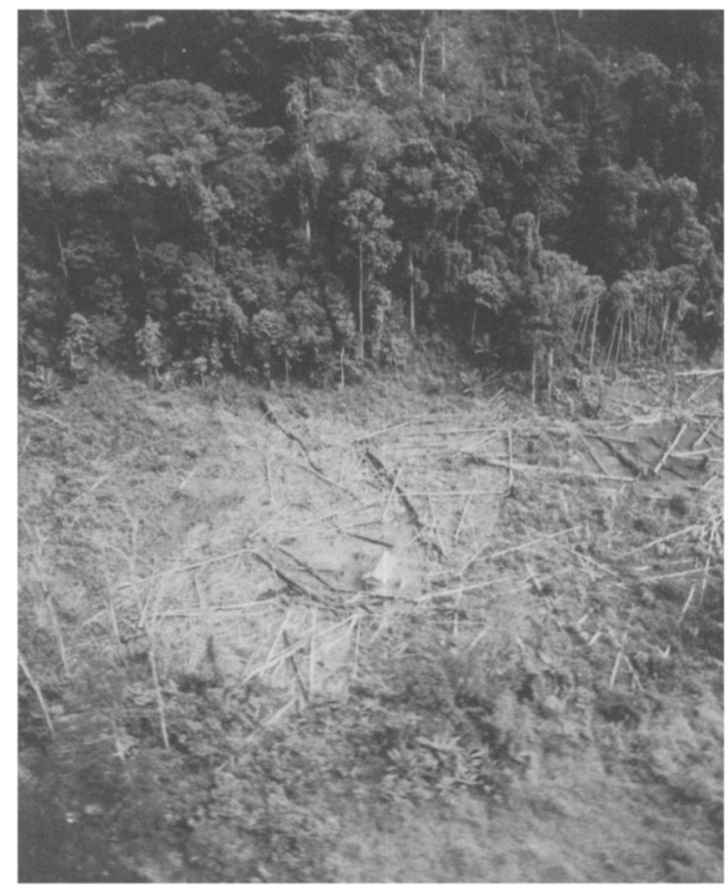

Table 2. Ecological characterization of the Alas River, from Gunung Leuser National Park to the Indian Ocean, Sumatra

\begin{tabular}{|c|c|c|c|c|c|c|c|c|}
\hline Section & End-points & $\begin{array}{l}\text { Length } \\
\text { in } \mathrm{km}^{*}\end{array}$ & $\begin{array}{l}\text { Portion } \\
\text { in park }\end{array}$ & Navigability & Topography & $\begin{array}{l}\text { Riverine } \\
\text { habitat type }\end{array}$ & $\begin{array}{l}\text { Influence } \\
\text { of humans }\end{array}$ & $\begin{array}{l}\text { Subjective } \\
\text { Impression } \\
\text { of wildlife } \\
\text { status }\end{array}$ \\
\hline 1. & $\begin{array}{l}\text { Gunung Leuser to } \\
\text { Agusan }\end{array}$ & 50 & $100 \%$ & $\mathrm{Nil}$ & $\begin{array}{l}\text { Very steep } \\
\text { gorge }\end{array}$ & $\begin{array}{l}\text { Pristine } \\
\text { rain forest }\end{array}$ & Nil & $\begin{array}{l}\text { Undisturbed } \\
\text { (?) }\end{array}$ \\
\hline 2. & $\begin{array}{l}\text { Agusan to } \\
\text { Ketambe Research } \\
\text { Station }\end{array}$ & 51 & $90 \%$ & $\begin{array}{l}\text { Class VI, team } \\
\text { of experts only, } \\
\text { portages }\end{array}$ & $\begin{array}{l}\text { Mostly steep } \\
\text { gorge }\end{array}$ & Rain forest & Minor & $\begin{array}{l}\text { Apparently } \\
\text { undisturbed }\end{array}$ \\
\hline 3. & $\begin{array}{l}\text { Ketambe to } \\
\text { Muara Setulen }\end{array}$ & 60 & $10 \%$ & $\begin{array}{l}\text { Class III to } \\
\text { Kutacane, then } \\
\text { dugout canoe }\end{array}$ & $\begin{array}{l}\text { Low gorge, } \\
\text { majority is } \\
\text { alluvial open } \\
\text { valley }\end{array}$ & $\begin{array}{l}\text { Agriculture } \\
\text { mostly, some } \\
\text { forest }\end{array}$ & Complete & $\begin{array}{l}\text { Impacted to } \\
\text { none } \\
\text { remaining }\end{array}$ \\
\hline 4. & $\begin{array}{l}\text { Muara Setulen to } \\
\text { Renun River }\end{array}$ & 32.5 & $45 \%$ & Dugout canoe & Steep gorge & Rain forest & Minor & $\begin{array}{l}\text { Lightly } \\
\text { impacted }\end{array}$ \\
\hline 5. & $\begin{array}{l}\text { Renun River to } \\
\text { Bengkong River }\end{array}$ & 11 & $50 \%$ & Dugout canoe & Low gorge & Rain forest & $\begin{array}{l}\text { West, minor } \\
\text { East, substantial } \\
\text { and increasing }\end{array}$ & Impacted \\
\hline 6. & $\begin{array}{l}\text { Bengkong River to } \\
\text { Gelombang }\end{array}$ & 58 & None & Motor launch & $\begin{array}{l}\text { Low hills, } \\
\text { open alluvial } \\
\text { valley }\end{array}$ & $\begin{array}{l}\text { Agriculture, } \\
\text { rain-forest } \\
\text { remnants, } \\
\text { secondary }\end{array}$ & $\begin{array}{l}\text { Impacted, } \\
\text { largest } \\
\text { mammals not } \\
\text { present }\end{array}$ & Impacted \\
\hline 7. & $\begin{array}{l}\text { Gelombang to } \\
\text { Indian Ocean }\end{array}$ & 110 & None & Motor launch & $\begin{array}{l}\text { Flat } \\
\text { alluvial } \\
\text { valley }\end{array}$ & $\begin{array}{l}\text { Agriculture, } \\
\text { some second } \\
\text { growth forest }\end{array}$ & Complete & $\begin{array}{l}\text { Almost } \\
\text { none } \\
\text { remaining }\end{array}$ \\
\hline
\end{tabular}

Information from US Army Map Service (Corps of Engineers) maps, Edition 1-AMS, Series T-503, Sheets NA 47-1, 2, 5, and 6 (1954). River joumey through Gunung Leuser NP 
of primates (with the exception of orang-utans, which I did not see, and their nests, which were relatively rare) appeared only slightly reduced below those of Section 4.

Section 6 consists of $58 \mathrm{~km}$ of the Alas from the Bengkong confluence to Gelombang. Low rounded hills attenuate to nearly flat topography. Human habitation predominates and the level of human modification to the riverine habitat increases with proximity to Gelombang. However, even in this section, on steep slopes with uncut blocks of rain forest I saw long-tailed macaques, pig-tailed macaques, langurs, siamang, and lar gibbons. But these 'island' habitats became ever more scarce as we travelled downstream.

Section 7, $110 \mathrm{~km}$ from Gelombang to the Indian Ocean, is ecologically almost an extension of Section 6. The main differences are that the topography is level and the influence of humans complete. During our round-the-clock combined descent and return to Gelombang, I saw only one group of langurs and one of long-tailed macaques, both in patches of secondary forest. Many people in Gelombang, however, own juvenile or adolescent long-tailed macaques, which can be purchased for US $\$ 10$.

Current laws regulating use of the Park by the people around it allow for continued access to some of its natural products under the 'adat' system. Adat refers simply to traditional cultural practices restricting the harvesting of forest produce. In short, people can still enter the Park to collect plants for medicinal or other personal needs, but not for commercial exploitation. In theory, the adat system is harmonious with the perpetuation of an ecosystem in a state close to that of nature. Rijksen (1978) points out that some adat restrictions 'appear to aim at conserving the delicate ecological balance in the clan's territory', but admits that this balance is preserved only if the population governed by adat is itself kept in balance by ecological and cultural factors. Because of the impact of newly imported ideologies, this is no longer the case. Over much of Sumatra, Rijksen warns, slash-andburn agriculture stripped of adat restrictions is highly destructive.

108

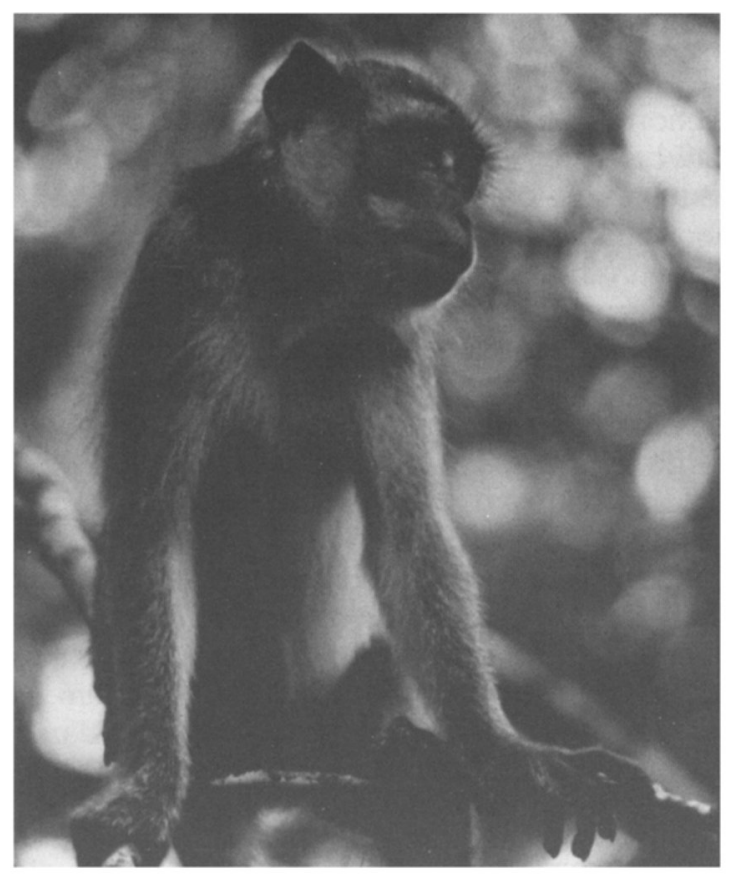

A long-tailed macaque, the most common primate of the riparian habitat of the Alas River (M.P. Ghiglieri).

The adat system is easily abused by extending it to commercial exploitation. Van Strien (1978) noted the local disappearance of commercial species of rattan in Gunung Leuser through overharvesting, for instance, and the local depletion of many dipterocarp species through the collecting of aromatic gums for the market by bark-girdling techniques, which kill the trees.

Other conflicts of interest exist between the goals of the Park and the needs of people living adjacent to it or within it. According to the Head of the Park, Mr Nasori S. Djajalaksana (pers. comm.), between 1979 and 1984, 19 people were killed by tigers in or near the Park in forest and peripheral villages. Stock losses were more frequent. During the same period, an average of two tigers per year were killed by poison bait or trapped by the park staff using live bait for transfer to zoos. In addition, elephants have occasionally destroyed crops, necessitating compensation payments (see also Caufield, 1984).

One solution is to move people out of the Park and/or to centralize those living on its periphery. Oryx Vol 20 No 2, April 1986 
Public education is vital for such moves to succeed, but even with it they are traumatic. The expensive failure of the Uning Puni relocation project sponsored by the World Wildlife Fund illustrates this difficulty. Hundreds of forest Gayo living in the Park and engaged in slash-and-burn farming were relocated to a new village along the Alas in Section 2. The standard allocation for such translocations is to provide each family with $2 \cdot 25$ ha for growing commercial crops plus another 1.5 ha for their subsistence garden (see Caufield, 1984). Within two years, the relocated Gayo abandoned Uning Puni and returned to the forest. Van Strien (1978) stressed the necessity to go beyond policing and public education by promoting land reforms, intensifying existing agriculture, and promoting family planning. However, public education of local people does remain a major need in the management of Gunung Leuser. Some local people reportedly believe it is a national park because the land has been bound as a lien for debts incurred by

Below: Abandoned relocation project at Uning Puni in Section 2 of the Alas River in non-park enclave (M.P. Ghiglieri).

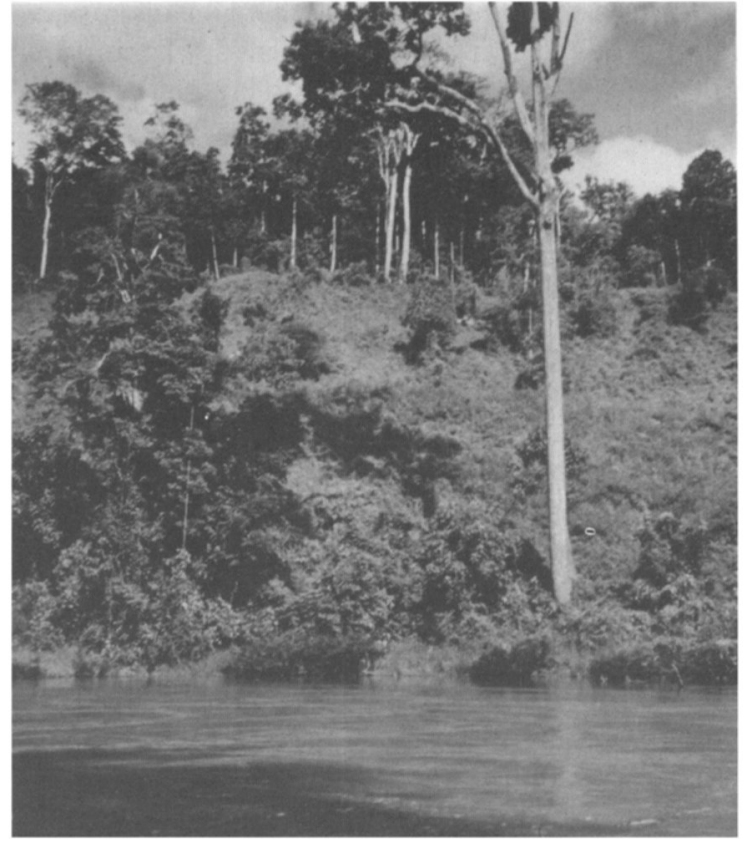

Above: Abandoned swidden plot $1 \mathrm{~km}$ upstream from the Lower Gorge (Section 4) near boundary of Gunung Leuser National Park (M.P. Ghiglieri).

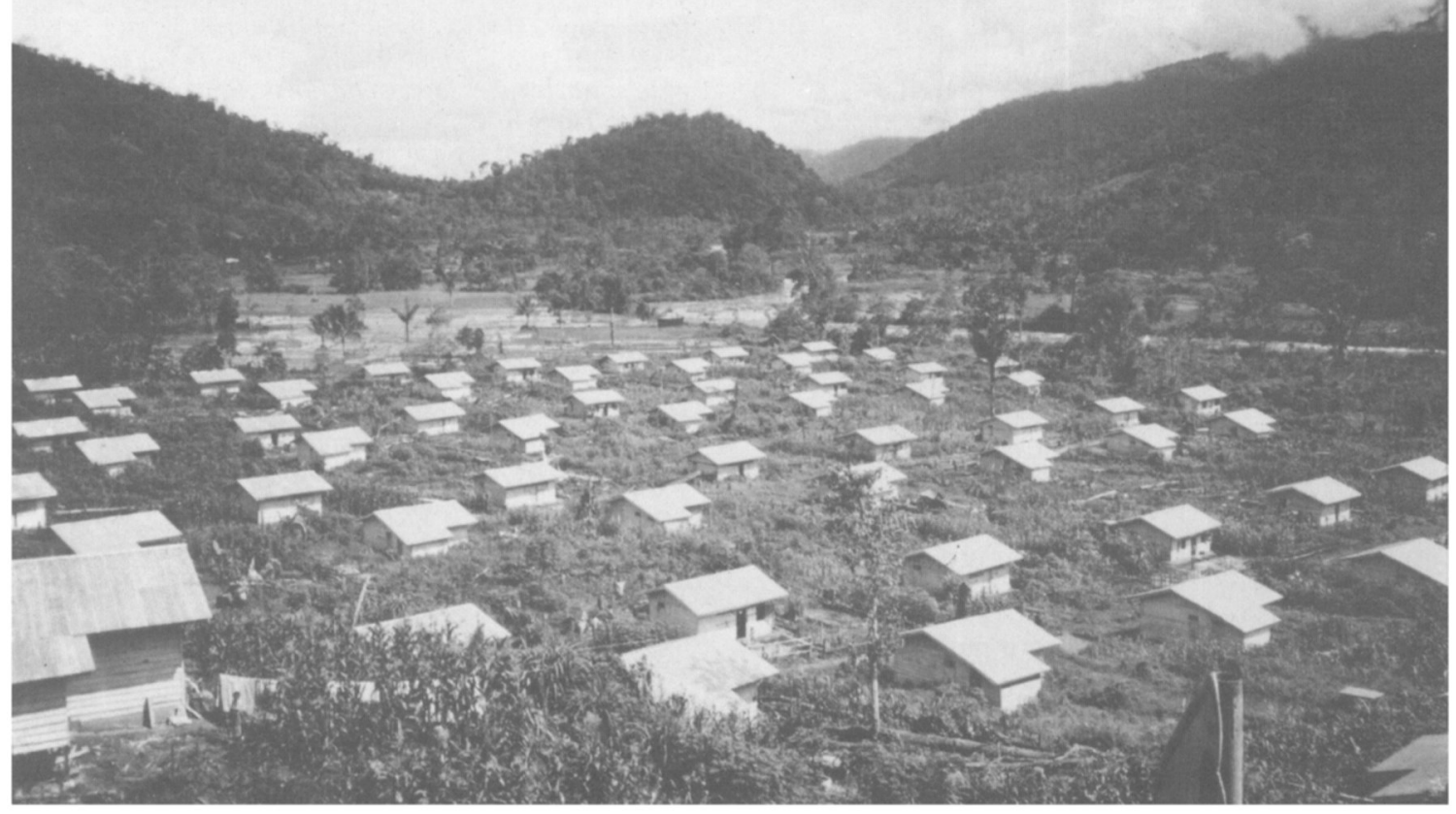


Indonesia to The Netherlands (J. DeRuiter, pers. comm. at Ketambe). This explains for them the otherwise difficult to understand interest of Dutch researchers at the Ketambe Research Station.

While expatriate researchers sometimes make good watchdogs against incursions into the Park, and often train their Indonesian counterparts to do the same, neither fundamentally alters local peoples' opinions about their own rights. Degradation of habitat due to incursions is a serious risk, one which threatens the genetic viability of populations of large mammals in the Park, for example orang-utans (Rijksen, 1982). In general, the growth of human populations around enclaves of great ape habitat seriously threatens the apes (Frey, 1978; Ghiglieri, 1984a, b). Mitchell (1984) recommended more surveys to categorize the distribution and abundance of habitat types and rare species in Gunung Leuser, plus more support for Indonesian graduate students in forest ecology to conduct research on the effects of human-caused perturbations on habitats, and more assistance to national park staff to revive the public relations programme of the 1970 s.

Along with public education, increased tourism should be promoted so that the Park may not only begin to pay for itself, but also pay some of the people living around it (Ghiglieri, 1984b). Although the orang-utan rehabilitation centre at Bohorok on the eastern side of the Park near Medan receives many local tourists and functions as an important centre for public education (Aveling and Mitchell, 1982), tourism in the Alas Valley is barely in its infancy. The potential for increasing it is great. Whitewater rafting, dugout canoeing in the Lower Gorge (both with riverside camping), photographic safaris, or guided ascents of Gunung Leuser are potentially lucrative industries, which should be subject to proper feasibility studies. Such developments should be considered more than desirable: they should be considered essential to the future of Gunung Leuser.

Despite its difficulties, Gunung Leuser as a national park is a triumph for conservation and a laudable achievement of world importance by the Government of Indonesia. Gunung Leuser's $7900 \mathrm{sq} \mathrm{km}$ are sufficient to sustain genetically 110 viable populations of several vanishing species, including orang-utans, tigers and rhinos. It is to be hoped that it is also large and healthy enough to resist the kind of catastrophic damage sustained by forests in East Kalimantan due to drought and fire in 1983 (Asiaweek, 1984). It acts as an important watershed, which is critical for agriculture downstream, provides numerous other services including climate moderation and carbon cycling (Woodwell et al., 1983), and is a storehouse of genetic diversity; the uses of many of its species remain to be assessed.

\section{References}

Asiaweek Staff. 1984. Wound in the world. Asiaweek. July $13,32-55$.

Aveling, R. and Mitchell. A.H. 1982. Is rehabilitating orangutans worthwhile? Oryx, 16, 263-271.

Blouch. R.A. 1984. Current Status of the Sumatran Rhino and Other Large Mammals in Southern Sumatra. World Wildlife Fund: IUCN/WWF report no. 4, Project 3033 field report.

Caufield. C. 1984. Pioneers of the outer islands. Natural History. 93(3), 22-32.

Frey, R. 1978. Management of orang-utans. In Wildlife Management in Southeast Asia (Eds J.A. McNeely, D.S. Rabor, and E.A. Sumardja), pp. 199-217. Biotrop., Bogor. Indonesia.

Ghiglieri, M.P. 1984a. The Chimpanzees of Kibale Forest. Columbia University Press. New York.

Ghiglieri, M.P. 1984b. The mountain gorilla: last of a vanishing tribe. Mainstream, 15, 3-4, 36-40.

MacKinnon. J. 1974. The behaviour and ecology of wild orang-utans (Pongo pygmaeus). Anim. Behav. 22,3-74.

Martin, E.B. 1983. Rhino Exploitation in India, Indonesia, Malaysia, Burma, Japan, and South Korea. World Wildlife Fund. Hong Kong.

Mitchell. A.H. 1984. Primate Conservation and the Gunung Leuser National Park. Indonesia. IUCN/SSC Primate Specialist Group Newsletter no. 4; 40-41.

Myers, N. 1984. The Primary Source. W. W. Norton. New York.

Rijksen. H.D. 1978. A Fieldstudy on Sumatran Orang-utans (Pongo pygmaeus abelii Lesson 1827) Ecology. Behaviour and Conservation. H. Veenman \& Zonen B.V., Wageningen. The Netherlands.

Rijksen. H.D. 1982. How to save the mysterious 'man of the forest'? In The Orang-utan. Its Biology and Conservation (Ed. L.E.M. de Boer). pp. 317-341. Dr W. Junk, The Hague.

Van Strien. N.J. 1978. Management Plan for the Proposed Gunung Leuser National Park. World Wildlife Fund Report.

Woodwell, G. M., Hobbie J.E., Houghton, R.A., Melillo, J.M. Moore. B. Peterson. B.J. and Shaver. G.R. 1983. Global deforestation: contribution to atmospheric carbon dioxide. Science. 222, $1081-1086$.

Michael P. Ghiglieri, 814 N. Leroux, Flagstaff. AZ 86001. USA.

Oryx Vol 20 No 2, April 1986 